\title{
Rural Tourism and New Township Development: A Study of Jiuzhou, Guizhou Province, China
}

\author{
Lei $\mathrm{Wu}^{1}$, Tai-Chee Wong2* \\ ${ }^{1}$ Guizhou Provincial Department of Housing and Urban-Rural Development, Guiyang, China \\ ${ }^{2}$ Faculty of Humanities \& Social Sciences, Southern University College, Johor, Malaysia \\ Email: *tcwong@sc.edu.my
}

How to cite this paper: Wu, L., \& Wong, T.-C. (2017). Rural Tourism and New Township Development: A Study of Jiuzhou, Guizhou Province, China. Current Urban Studies, 5, 387-402.

https://doi.org/10.4236/cus.2017.54022

Received: September 19, 2017

Accepted: November 24, 2017

Published: November 27, 2017

Copyright $\odot 2017$ by authors and Scientific Research Publishing Inc. This work is licensed under the Creative Commons Attribution International License (CC BY 4.0).

http://creativecommons.org/licenses/by/4.0/

\begin{abstract}
Peasantry is symbolic of China's rural poverty, especially in mountainous provinces such as Guizhou. Recent public campaigns in China to modernize rural regions have much focused on organizing peasants to be urbanized, and engaged in higher value services, one of which is tourism. The paper has used Jiuzhou, a small township in Guizhou to examine its rural urbanization process through land value enhancement and human resource redeployment of local workforce. Jiuzhou's proximity to the famous tourist site, Huangguoshu, and its easy access to a trans-province highway and its own heritage attractions have been an enabling power to raise its economic status. The study has found a close relationship between the urban-based tourism development and the pace of urbanization, and local tourism development has held back local residents to some extent from migrating out. Growth has generated greater demand for goods and services which in turn has stimulated higher levels of consumption pattern. Nevertheless, many state-run travel agencies were reported to be more dedicated to "image engineering" than market competition, and environmental conservation, the key for eco-tourism, has been somehow overlooked.
\end{abstract}

\section{Keywords}

Jiuzhou Township, Rural Urbanization, Peasants, Tourism, Income Levels, Market

\section{Introduction}

The issues relating to agriculture, rural villages and peasants, known as the 
"sannong" (literally meaning the "tri-agricultural" issues), are at the core of China's rural economic development. The problems further extend to disputes relating to social justice and could possibly be a hindrance towards the realization of modernization in China. Without the support of agricultural and rural modernization and improvement of peasants' well-being, it is meaningless to talk about rural prosperity. As such, it is critical to resolve the "tri-agricultural" issue before China could move towards a modern society and the path lies primarily with rural modernization and rural urbanization (Han, 2007).

Rural urbanization is widely believed to be capable of narrowing down rural-urban disparity leading to the ultimate elimination of their dualistic feature, and to promote localized industrialization and enhance land values through coordinated and more productive deployment or organization of human and land resources supported by capital input. Economic structural change brought about by urbanization moreover could help modernize low-income rural societies and hence raise their incomes to a higher level (Zhang et al., 2013). Among the many possible ways to bring about such transformation, rural tourism has shown to have great potential, especially at this historical juncture where China, almost 40 years after the advent of economic reforms, has entered a new phase which requires a renewed impetus driven by high-value service chains of development. Hotel development, for example, is a possible high value chain business that may be promoted by growth in per capita income, highway access, rising urban active population and influx of tourists (Huang et al., 2015; Zhang et al., 2013).

As it is generally known, tourism is not only a rising industry in the long-term, but also has an advantage in its broad-based connectivity in both capital and human skills to other support services where peasants have more or less some capacity to take part. According to "China's Tourism Investment Report, 2014", rural tourism in 2014 recorded a total of 1.2 billion passenger-trips, accounting for almost one-third of the total national volume. From its total revenue of 320 billion yuan, rural tourism had enabled 33 million peasants to be engaged in this booming industry and share the newly generated wealth. As of 2014, there were about 2 million rural businesses and over 100,000 villages with local unique features in China that have potential to be positively involved in rural tourism (Fenghuangwang, 2015; Lu, 2015).

In line with this growing trend of rural tourism, the Chinese government has seen an opportunity to integrate this sector with its new rural urbanization policy, and as a point of penetration and strategy to tackle the "sannong" problem head-on. In early 2014, the Chinese State Council promulgated a plan, known as “The New National Urbanization Program, 2014-2020”, specifying rural tourism as a key contributing element. In preparing for a post-industrial phase of national development, this program aims to use urbanization as a growth engine and to build up a "people-oriented, ecologically civilized, agglomeratively efficient and culturally inheriting pathway, serving the joint interest of the four moderniza- 
tions and the objective for an integrated rural-urban society" (Lu et al., 2013).

This paper uses a case study of Jiuzhou in Guizhou province to elaborate the ways in which tourism is assumed the role to lead the path of urbanization and explain why it is an important economic development option in the ecologically fragile and mountainous yet scenic and charming Guizhou. In parallel, the existing problems and the role of the state in promoting local tourism as a means of narrowing down the gap between more developed coastal regions and less developed inner provinces such as Guizhou are examined.

\section{Research Rationale and Method}

Joseph E. Stiglitz, a Nobel laureate, once suggested that urbanization in China and the high-tech development in the United States were two key respective factors in the twenty-first century that would have overwhelming influence on global development (Han, 2007). Undeniably, as we have noticed, in nearly four decades after the reforms, China's urbanization rate had leaped from 17.9 percent in 1978 to 56.1 percent in 2015, showing a consistently high average growth rate of one percentage point per year. Given the large gaps between urban and rural areas in China and its high concentration of rural population working predominantly on tiny farm plots, its pace of rural urbanization and rural modernization has become a crucial factor of development in the next couple of decades. More importantly, the direction of rural urbanization has to rely on qualitative transformation to relieve population pressure and create more productive opportunities rather than just creating jobs to meet basic needs (Xiao, 2005).

With such a rationale and focus on qualitative change of China's economy through an urbanization path, this study has adopted an on-the-spot investigation in Jiuzhou, Guizhou province where formal and informal interviews were conducted in three occasions in 2015. The first survey was made with five local public officials on public policy matters and how they assessed the participation of local peasants and investors, as well as their prospects of public policy in promoting tourism activities. The second occasion covered informal and unstructured discussions with some 10 township residents and peasants on their views on tourism. The third survey aimed at the small business sector which comprised about 10 local and outside investors identified in the Jiuzhou Township. Local investors were those peasants who still tilled their land but were also engaged in small businesses. In ensuring a greater chance of success, such businesses were very much those related to their personal skills and livelihood experiences. From facts and empirical evidence collated, an analysis was undertaken to examine how the path has evolved over time, the extent of socio-economic change was felt and experienced in the interviewees' personal perceptions, based on which the effectiveness of this rural tourism-led urbanization model was analyzed. In particular, attention was paid on how well local tourism was in a position to hold back local residents from flowing into large cities as migrants as it is the case in China today. 
A large volume of secondary sources from published library and online materials was referred to with an objective to examine the relationship between rural tourism and urbanization pathway. Statistical data from governmental departments, and socio-economic change in relation to such transformation are used to support the arguments of this study.

\section{Literature Review}

\subsection{General Discussion of Relationship between Urbanization and Rural Tourism}

Traditionally in the pre-industrial age, travelling was hardly interpreted as tourism. It was largely non-leisure oriented and was rather an absolute necessity in terms of trade, exploration, military conquest or seeking refuge. Taking the perspective of today, however, tourism is primarily a post-war phenomenon and has acted as a stimulus to activate urban growth as it relies essentially on the rise of disposable incomes and advancement of affordable transport technology. Rise in disposable incomes took off first in the capitalist Western societies from the 1960s following their successful economic recovery from the ruins of World War II. This trend later diffused to less developed countries when air and land travels became more affordable with the rising numbers of middle classes.

Destinations of tourism are very much site dependent, whether they are for business or leisure-seeking. For European holiday makers, island resorts in the Mediterranean areas are an attractive pole for their sandy beaches, and sunny ambience. In this sense, the Balearic Islands off Spain's east coast have experienced significant tourism-led urban growth since the 1950s. The most significant socio-spatial transformation of this small archipelago is reflected by the chain of hotels built along their coastal zones appealing to European tourists.

In a recent study by Pons et al. (2014), the research group examined the urbanization form that had developed in the Balearic Islands during the period 1936-2010. Besides the tourist dollars that fed the local economy, they found that the choice of access routes and sites by local and foreign investors and public institutional support played a key role in influencing the scale of resorts. Again, the concentration of population set the momentum of tourism's consumption-based dynamics that determined the settlement sizes and intensity of activities. Accordingly, tourism development had triggered dramatic change in the economic structure of the archipelago, transforming its agricultural component from 40 percent in the 1950s to a low one percent of today. Meanwhile, the Balearic population rose over 260 percent from 420,000 in 1950 to 1.1 million in 2011, thanks to the earlier baby boom and migratory waves from the Spanish mainland and less developed Africa pulled in to serve the tourism industry. The pace of fluxes corresponded with the post-Fordist production system developed from the late 1970s which led to higher incomes in more advanced capitalist states and more sunshine searching tourists. Urban growth in the Balearic Isl- 
ands was also significantly attributable to revenues being pumped back from the Spanish government towards the construction of a pro-tourism institutional framework. Tourist resorts were initially clustered in proximity to transport nodes such as Palma's port and airport before they spread to other hotspots around the Bay of Palma, and later beyond (Pons et al., 2014). However, rising global competition in tourism ventures from the 1990s has forced bigger players to form coalitions and merger of businesses, hence edging out smaller firms. Consequently, the Spanish authority began to diversify its focus to other parts of the country and this has slowed down urban growth on the archipelago as public attention has also been shifted to accommodate international elites with the development of coastal luxurious homes (Pons et al., 2014).

In China, the state interest in tourism-led urbanization has produced identical impact on urban growth through its initiation of institutional and policy-making processes. Indeed, effective implementation of tourism policy is a decisive factor in determining success or failure especially in a country where the government is highly bureaucratic and has played an overwhelming role in bolstering rural urbanization (Wong, 2015; Wang, 2014). The role of domestic tourism has been increasingly seen by the Chinese state as a key demand-side and consumption-based source of economic growth. From 2009, tourism has been promoted as one of the "five consumption spots" with the capacity to boost aggregate demand, create employment opportunities and help balance development of a vast country made up of highly unevenly developed regions (Airey \& Chong, 2010).

Chinese scholars are mostly positive about the relationship between rural tourism and urbanization. A number of researchers have addressed that rural tourism which is relatively new in China could have even contributed to a new type of urbanization. Zhen and Luo (2007) argue that any urbanization movement whether it is activated by rural tourism or not tends to induce improvement in rural infrastructure and enhance the function of local economic structure. With higher economic values generated in the urbanization process, urban activities would be promoted to help transform the local economic base from a traditional one towards a modern one. Lu and Ge (2006) share similar inclination of thought, highlighting that the new urbanization campaign driven by the government investment would definitely bring about spread effects to the rural sector and tourism thereof may be defined as an engine of growth and key factor of production if sizeable volumes of tourists are attracted to spend their money there. Therefore tourism can be seen as a service sector of rising significance that would serve as a model for urbanization pathway.

Zhang and Li (2015) go into a broader regional scope of rural tourism development. They are of the opinion that rural tourism is the focal point where agricultural modernization and new urbanization development meet and from which tourism would contribute towards a regional dimension of socio-economic development. In such a process, urban growth would play the leading role in upbringing the rural sector, supporting hence modern agricultural development 
and, through implementation of the new village model ${ }^{1}$, enriching the wealth of local population. Fan's (2015) interest is more on the inflow of capital, a key factor seen as highly important to enable rural tourism to be promoted more holistically, and benefit urbanization as a consequence to function in an effective scale.

The review provides a general consensus that there is a positive interactive relationship between rural tourism and urbanization development, and through their interactions, a higher level of economic achievement has been attained. Indubitably, however, there remain problems such as the types of economic activities selected are not always the best options for good returns, inadequate environmental protection, negligence in historic and cultural conservation efforts and interests of peasants might be overlooked.

\subsection{Examples and Problems}

\subsubsection{Tuanjie Township of Kunming Municipality}

Tuanjie Township is located in the western suburb of Kunming Municipality, Yunnan province. In 1998, the township developed its first "nongjiale" (farmstay inn) to promote urban development. In seven years, the township had seen a drastic change in its economic structure. Such change saw an increasingly diversified economic output moving from its 1998's primary sector (35\%), secondary sector (44\%) and tertiary sector (21\%) to $19.7,25.0$ and 55.3 percent respectively in 2005. From an agriculture-based economy, the township has managed to mobilize its surplus farm labour towards the development of an in-situ service-led sector predominantly driven by tourism supported by transport and communications, finance, catering, hotel and other commercial activities (Fan et al., 2015). With the generated revenues from tourism, Tuanjie Township has upgraded its physical infrastructure and succeeded in building up a series of private businesses involved in the promotion of tourism.

\subsubsection{The Interactive Development of Tourism and Urbanization in Leishang County}

Leishang County is situated in the southwestern part of the Autonomous Prefecture of Miao and Dong Minority Groups in Qiandongnan, Guizhou province where minority groups occupy 91.4 percent of the total population. The county is typically and highly concentrated by the Miao people who make up 84.2 percent of the total. In 2006, the county government started vigorously to develop its tourism sector by setting a strategic objective which aims to "create a reputable eco-tourism county nationally known for the integration of its primitive

\footnotetext{
${ }^{1}$ The basic principles of the new village construction consist of building up the rural sector into an economically prosperous, environmentally harmonious and a socially well-equipped society. As stipulated in the Fifth Plenary Session of the 16th Central Committee of the Chinese Communist Party held in 2005, the new village should meet the objectives of "promoting productivity, material wealth, a high level of rural civilization, a neat and tidy living environment and a democratic style of management" (Baidubaike, 2005).
} 
Miao culture and natural beauty" (Jiang, 2010). With an investment of over 100 million yuan from the government, such move has indeed bolstered the county's performance and upgraded its economic function and structure within a short span of time. In three years from 2005 to 2008, incomes generated by tourism had increased by 8.4 times from 34.1 million yuan to 285.1 million yuan contributing 47.5 percent towards the local GDP output. The above two cases have shown that both farmer-initiated moves and public sponsorship have worked to promote tourism at the local level. Public sponsorship has indeed proved to be more effective in producing positive results.

\subsubsection{Existing Problems}

As it is already known to many, especially during the early stage of tourism development, enterprises organizing their business plans tend to be over-simplistic and superficial in approach to suit the taste of tourists by initiating largely commercialized projects. Firstly, managers of enterprises are more inclined to adopt large-scale modern city-based facilities and buildings to show off the grandeur of projects while ignoring the real substance of local ethnic features. This has led to the loss of indigenous identity, and local culture and history in their touristic presentation to visitors.

Secondly, for the sake of cost-saving, the functions of tourism have been simplified and standardized, and the mutual supportive capacity between regional travel agencies is often overlooked, thus resulting in a weak sectoral linkage. Given that travel agencies are developed each on their own merit with little or no coordination among one another and due to their dispersed pattern in operations, they are unable to achieve agglomeration effects and economies of scale.

Thirdly, as observed, conflicts between tourism development and ecological protection measures have intensified. Rapid expansion of rural tourism and the substantial rise in tourist numbers have resulted in unproductive use of land converted from farming, rising problems of noise and air pollution, as well as indiscriminate discharge of waste water and garbage (Fan et al., 2007). The consequence is that this has inflicted much damage to the natural environment, and at this juncture, the case of Jiuzhou is a case in point for a close examination.

\section{The Case of Jiuzhou Township}

\subsection{Background}

Jiuzhou is located in the central part of Guizhou province, $37 \mathrm{~km}$ northeast of Anshun municipality and $75 \mathrm{~km}$ west of Guiyang city. The township is also just $84 \mathrm{~km}$ from the famous waterfall resort "Huangguoshu" (see Figure 1). The township covers a total area of $116 \mathrm{sq}$. $\mathrm{km}$, of which 8.9 sq. $\mathrm{km}$ has been earmarked as a planning zone, and it has a population of 43,790, with 8070 living in the urbanized area.

The settlement was first built in 1351 as a frontier town during the Yuan Dynasty (1279-1368), and later became a strategically important military base of 


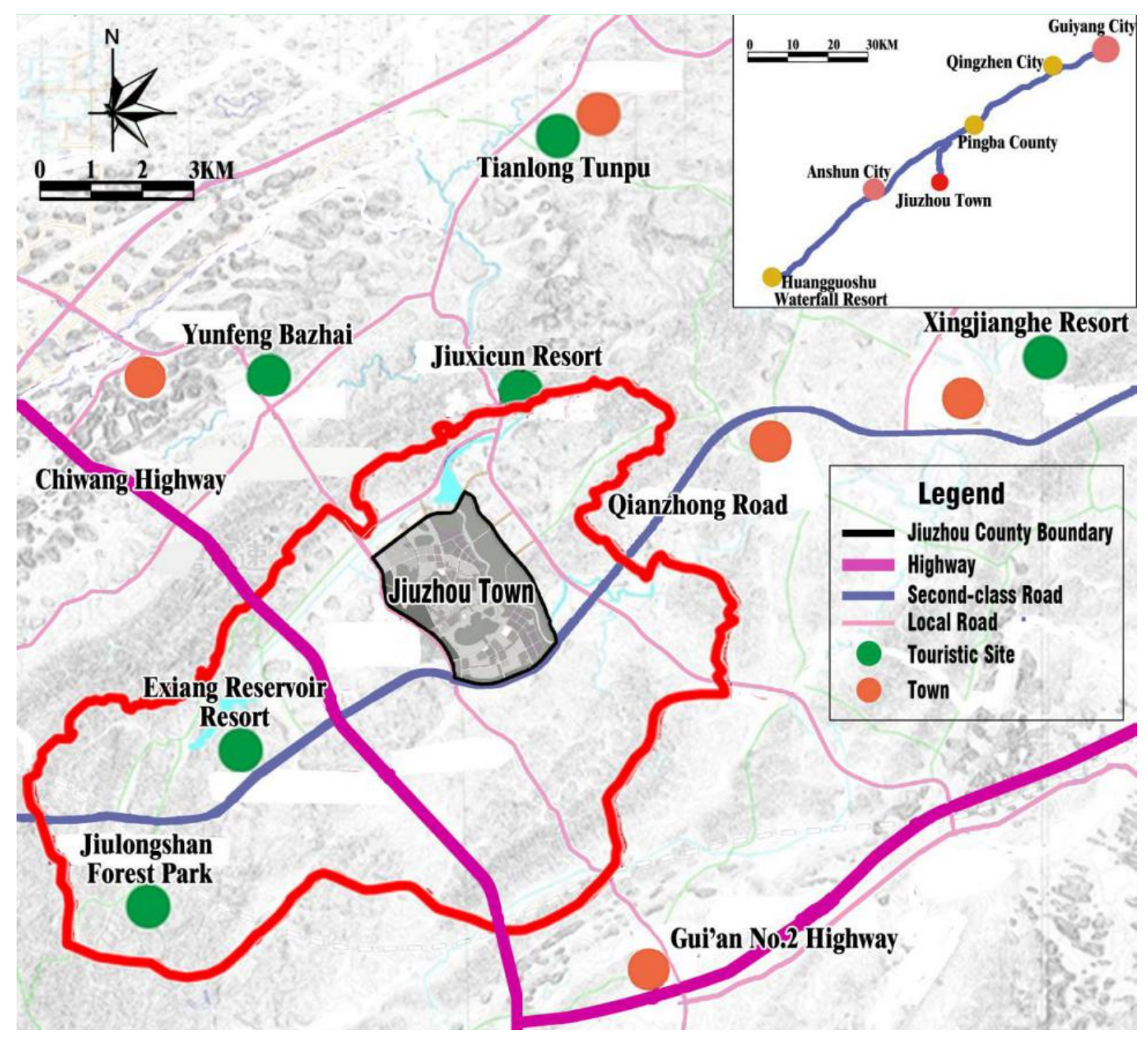

Figure 1. Location of Jiuzhou Township and touristic sites nearby.

Zhu Yuanzhang, the founding emperor of Ming Dynasty (1368-1644) who used the base to "pacify" the ethnic minorities. During the eighteenth and nineteenth century, the town once developed itself into a prosperous centre of trade and handicraft. In 2008, Jiuzhou was proclaimed a national class of historic and cultural township. In 2013, it was further elected by the Chinese government as a class $4 \mathrm{~A}$ eco-cultural tourism site for its low-carbon greenery and wetland recreation park (China National Tourism Administration, 2014).

\subsection{Jiuzhou Tourism within Guizhou Province}

In touristic terms, Jiuzhou lies within a relatively well connected region of Guizhou province which is covered by 92.5 percent of mountainous and hilly terrains characterized by predominantly karst topography. Known as a "park-like province", Guizhou is free from severe winter and harsh summer. Nearly half of the province is still covered by natural forest with a rich bio-diversity. This means the province is endowed with a unique advantage for the development of eco-tourism. 
Over the past three decades, Guizhou has indeed experienced a sharp growth in its service sector, which made a contribution towards the local economy from 18.2 percent in 1978 to 47.9 percent in 2012 (Table 1). Characteristically during the early period of reforms, manufacturing and construction took the lead in sectoral growth but from around 2005, the service sector became the new leader with the help of particularly tourism. Obviously, such trend is expected to continue. In 2011, rural tourists in Guizhou accounted for a total of 56.05 million passenger trips, recording about one-third of the total tourist numbers and a revenue of 22.14 billion yuan. Jobs thus created had benefited 1.05 million villagers in the province and another three million people were estimated to have benefited indirectly from the growth of tourism (Jinqian Zaixian, 2012; Baidubaike, 2015).

Jiuzhou is directly administered under the jurisdiction of Anshun city which has benefited enormously from its nearby Huangguoshu Waterfall which draws visitors from the whole of China and abroad. In 2012, for instance, Anshun received a tourism revenue of 19.5 billion yuan, a 58-fold increase from its low base in 2002 (Baidubaike, 2016). In 2015, Jiuzhou succeeded in attracting 0.52 million visitors, generating an income of 253 million yuan. We now look at whether there are trickling down effects to Jiuzhou which are conducive to its urban growth given its proximity to Anshun and the resort.

\subsection{Tourism Development in Jiuzhou and Urbanization}

Indeed, the rapid surge of tourism business in Jiuzhou has led to the restructuring of its economy. During the period 2008-2014, Jiuzhou's economic structural distribution had improved such that its primary sector fell in value from 70 to 27 percent and its secondary sector rose from 20 to 61 percent while the tertiary sector witnessed a rise from 10 to 12 percent. The significant rise in the secondary sector which includes construction was attributable to government-led investment in infrastructure and public facilities to support tourism growth. This move helped build up substantially a solid fixed asset capital in the township (Table 2).

The build-up of public infrastructure has laid the foundation in facilitating

Table 1. Change in gross domestic product of Guizhou province by sectors, 1978-2012 (Yuan RMB).

\begin{tabular}{cccccccccccccc}
\hline Sector & 1978 & $\%$ & 2000 & $\%$ & 2006 & $\%$ & 2008 & $\%$ & 2010 & $\%$ & 2012 & $\begin{array}{c}\text { Average Annual } \\
\text { Growth Rate (\%), } \\
1979-2012^{*}\end{array}$ \\
\hline Primary & 19.42 & 41.66 & 271.20 & 26.33 & 382.06 & 21.33 & 539.19 & 15.14 & 625.03 & 13.58 & 891.91 & 13.02 & 4.70 \\
Secondary & 18.73 & 40.18 & 391.20 & 37.98 & 967.54 & 41.37 & 1370.03 & 38.47 & 1800.06 & 39.11 & 2677.54 & 39.08 & 11.70 \\
Industry & 15.24 & 32.69 & 328.73 & 31.92 & 839.13 & 35.88 & 1195.30 & 33.56 & 1516.87 & 32.96 & 2217.06 & 32.36 & 11.90 \\
Construction & 3.49 & 7.49 & 62.47 & 6.07 & 128.41 & 5.49 & 174.73 & 4.91 & 283.19 & 6.15 & 460.48 & 6.72 & 10.10 \\
Tertiary & 8.47 & 18.17 & 367.52 & 35.68 & 989.38 & 42.30 & 1652.34 & 46.39 & 2177.07 & 47.31 & 3282.75 & 47.91 & 12.50 \\
Total & 46.62 & 100.0 & 1029.92 & 100.0 & 2338.98 & 100.0 & 3561.56 & 100.0 & 4602.16 & 100.0 & 6852.20 & 100.0 & 10.00 \\
\hline
\end{tabular}

Source: Guizhou Bureau of Statistics, 2013. Guizhou Statistical Yearbook 2013, Tables 1-3. Note: ${ }^{\star}$ The real growth rate needs to be moderated downward, given the relatively high rates of inflation over the period 1979-2012. 
Table 2. Socio-economic change of Jiuzhou Township, 2008-2014.

\begin{tabular}{|c|c|c|c|c|c|c|c|c|}
\hline $\begin{array}{l}\text { Socio-economic } \\
\text { Indicators }\end{array}$ & 2008 & 2009 & 2010 & 2011 & 2012 & 2013 & 2014 & $\begin{array}{c}\% \text { Change } \\
\text { in value } \\
2008-2014\end{array}$ \\
\hline Primary sector & 13,954 & 13,785 & 13,805 & 13,687 & 20,576 & 25,963 & 30,418 & +118.0 \\
\hline Secondary* ${ }^{*}$ sector & 3988 & 4351 & 4744 & 5393 & 12,977 & 16,812 & 68,121 & +1608.2 \\
\hline Tertiary sector & 1988 & 2014 & 2111 & 1900 & 3206 & 6090 & 13,282 & +568.1 \\
\hline Fixed asset investment & n.a & n.a & n.a & 27,761 & 43,269 & 80,238 & 125,764 & +353.0 \\
\hline $\begin{array}{l}\text { Farmer's per capita } \\
\text { annual income }\end{array}$ & 3382 & 3692 & 3991 & 4256 & 5448 & 6984 & 9347 & +176.4 \\
\hline
\end{tabular}

Source: Jiuzhou People's Government, Xixiu District, Anshun Municipality, 2015 (adjusted). Note: Currency unit: All indicators are in 10,000 yuan except farmer's per capita annual income. ${ }^{\star}$ Including manufacturing, farm produce processing and construction. n.a $=$ data not available. The percentage change for fixed asset investment is from 2011 to 2014 .

not only tourist access but also valorize land use through conversion of farmlands to urban setting. In this process, the primary sector has witnessed on the one hand, the substantive use of modern technology brought in from outside and marketing of its products. On the other hand, the farmlands have been transformed into modern show-farms designed for visitors' leisure and recreational use. From a virtually traditional setting, rural lands following their use conversion and modernized build-up have been able to discharge farmers into many tourism-related activities. Being a key component of the secondary sector, construction works which cover the development of hotels, reception centres, catering services, clinics, old folks homes, car parks and shopping centres to accommodate tourists have dramatically changed the rural landscape into an urbanistic morphology. It is also worthy of mentioning the relatively slow rise in the services during the period 2008-2012, which implies clearly the impact of tourism on the local economy has yet to come in the longer term.

By 2015, according to a local report, about 6000 villagers in and around Jiuzhou Township had been recruited to work as urban employees, among whom over 1000 were migrant workers coming from outside Jiuzhou (Jinri Toutiao, 2016). To a great extent, employing farmers to work in situ has helped achieve the objectives such as "leaving farming but working in the same locality", "in situ urbanization" and ensuring that farmers would not lose their land rights, yet stay employed. A key socio-economic change is that the villagers have now multiple sources of occupations. These comprise of incomes from farming, rental by leasing out premises to tourists, running small homestay business with catering services, as employees for local enterprises and sharing dividends and other revenues from cooperatives to which they have joined as shareholders after they have converted their farms to business undertakings. As reflected in Table 3, the most significant change is the sharp rise of urban population from 2008 to 2015, despite the fact that the urban population made up only 18.3 percent of the total population. 
Table 3. Population change of Jiuzhou Township, 2008-2015.

\begin{tabular}{cccccccccc}
\hline $\begin{array}{c}\text { Types of } \\
\text { Population }\end{array}$ & 2008 & 2009 & 2010 & 2011 & 2012 & 2013 & 2014 & 2015 & $\begin{array}{c}\text { \% Change } \\
2008-2015\end{array}$ \\
\hline Registered & 38,705 & 38,765 & 38,940 & 42,724 & 43,114 & 43,348 & 43,573 & 43,791 & +13.1 \\
Regular & 36,962 & 37,456 & 36,880 & 37,954 & 38,030 & 38,354 & 38,660 & 38,860 & +5.1 \\
Urban & 1544 & 1560 & 1630 & 4699 & 3684 & 3772 & 6570 & 8017 & +419.2 \\
Rural & 37,161 & 37,205 & 37,310 & 38,025 & 39,430 & 39,576 & 37,003 & 35,774 & -3.7 \\
\hline
\end{tabular}

Source: Jiuzhou people's government, Xixiu district, Anshun Municipality, 2016 (adjusted).

\subsection{Potential Dynamics of Tourism in Jiuzhou}

In view of its rapid growth in recent years as a result of substantial government support, the question arises as to whether tourism in Jiuzhou is sustainable in the longer term. At this point, it is noted that government support may be critical in the initial stage, but its long-term sustainable achievement will have to rely on the site's own endowments and potential dynamics based on which entrepreneurial efforts might follow suit to add values on.

In 2013, Jiuzhou Township was classified by the Guizhou government as a Class $4 \mathrm{~A}$ tourist site and as a physical landscape model for developing provincial tourism. This promotional election has helped Jiuzhou to win large provincial grants in land development, prestigious treatment in the deployment of capital, manpower and other social protection measures. What then are the potential dynamics of local resources and advantages to help Jiuzhou in its future undertakings? In this regard, one has good reasons to be optimistic if one is to consider the comparative advantages of the township in terms of its conserved natural environment, and cultural and historic heritage.

Table 4 shows a series of natural and cultural heritage that Jiuzhou enjoys as a valuable asset of tourism. There are mountains and a hill lying within and around the township which is dissected by a river. As an old strategically located township, its ancient moat canal as a waterbody and military defence layout have been retained. Alongside its traditional and "nostalgic" streetscape, temples are found across the old centre and in the midst of residential houses, a few of which are the legacy of some legendary families. Added to these are the social and cultural heritage of local ethnic minorities such as Miao and Buyei whose customary and traditional folk dances and songs are much a treasure in convincing visitors to stay overnight to watch their performances while enjoying their specialty dishes. Figures 2-4 give a general view of local streetscape and traditional ambience.

\subsection{Tourism's Role as a Consumption-Driven Factor and Prospects}

As a historic township situated deep in the inner province like Guizhou, Jiuzhou's tourism prospect would have to rely more on domestic visitors than those from abroad. Tourism growth is highly reflected by rise in disposable incomes of 
Table 4. Natural resources and cultural and historic heritage, Jiuzhou Township.

\begin{tabular}{|c|c|c|}
\hline $\begin{array}{l}\text { Natural } \\
\text { elements }\end{array}$ & $\begin{array}{l}\text { Mountains/ } \\
\text { hills } \\
\text { Waterbodies }\end{array}$ & $\begin{array}{l}\text { South River (moat canal), Xingjiang River } \\
\text { Farms }\end{array}$ \\
\hline & $\begin{array}{l}\text { Traditional } \\
\text { layout }\end{array}$ & "Hulou-style", unique features of military defence system \\
\hline Social elements & Streets/lanes & $\begin{array}{l}\text { East Street, South Street, West Street, North Street, } \\
\text { Beihou Street, Qidaokan, Zhongjia Lane, } \\
\text { Liujia Lane, Autumn Trees Park, Tangjia Bay etc. }\end{array}$ \\
\hline & $\begin{array}{l}\text { Traditional } \\
\text { houses }\end{array}$ & Fortress homes, Ancient residence of Gu family \\
\hline $\begin{array}{l}\text { Historic } \\
\text { buildings }\end{array}$ & $\begin{array}{l}\text { Religious } \\
\text { buildings }\end{array}$ & $\begin{array}{c}\text { Wanshou Palace, Guanyue Temple, Chenghuang } \\
\text { Temple, Catholic Church, Huguang Temple, } \\
\text { Qingyuan Palace, Arctic Temple }\end{array}$ \\
\hline Historic & Bridges & Tianbao bridge, 25 -eye bridge \\
\hline Infrastructure & Ancient city wall & \\
\hline \multirow{6}{*}{$\begin{array}{l}\text { Cultural } \\
\text { heritage }\end{array}$} & $\begin{array}{c}\text { Folk } \\
\text { festivals }\end{array}$ & $\begin{array}{c}\text { Traditional Ethnic Culture Festivals held on "May 28" } \\
\text { and "April 8" of lunar calendar }\end{array}$ \\
\hline & $\begin{array}{l}\text { Folk custom } \\
\text { activities }\end{array}$ & $\begin{array}{l}\text { Local fortress drama, flower-dancing, lantern-dance of } \\
\text { miao minority, lusheng dance*, suona horn, } \\
\text { song competition for lovers etc }\end{array}$ \\
\hline & Folk art & $\begin{array}{l}\text { Nuo-style mask carving, lusheng musical } \\
\text { instrument making, batik, embroidery }\end{array}$ \\
\hline & Customary diet & $\begin{array}{l}\text { Glutinous rice cake, Chinese bacon, blood bean curd, } \\
\text { salted vegetables, special eight dishes, stewed pork, } \\
\text { sweetened rice, smelly bean curd, spicy chicken etc }\end{array}$ \\
\hline & Folk costumes & Fortress costumes, Miao costumes, Buyei costumes \\
\hline & $\begin{array}{c}\text { Eminent } \\
\text { persons }\end{array}$ & $\begin{array}{l}\text { Zhang Fan, The Three Members of Central Committee } \\
\text { from Gu Family, Zhou Zhimian, Jian Jingzhai }\end{array}$ \\
\hline
\end{tabular}

Source: Overall plan of Jiuzhou Township, Xixiu county, Anshun municipality (2013-2030), Jiuzhou people’s government. Note: ${ }^{\star}$ Lusheng (芦笙), a musical instrument made up of six bamboo pipes producing different tones when blown.

the population in general which determines the domestic consumption capacity. In 2015, China's GDP per capita had exceeded US\$ 8000 as against a much lower average of US\$ 4800 in Guizhou, one of the poorest provinces in China. It is anticipated that the continued economic growth will bolster higher disposable incomes and therefore more domestic consumption in tourism and other recreational activities (Dong, 2014).

As argued, public investment in Jiuzhou's infrastructure and health- and transport-related services will raise the platform of business interests in the township, many of which are found in the tourism sector. The development process has been the blessing of a mixed outcome. As the authors have personally 


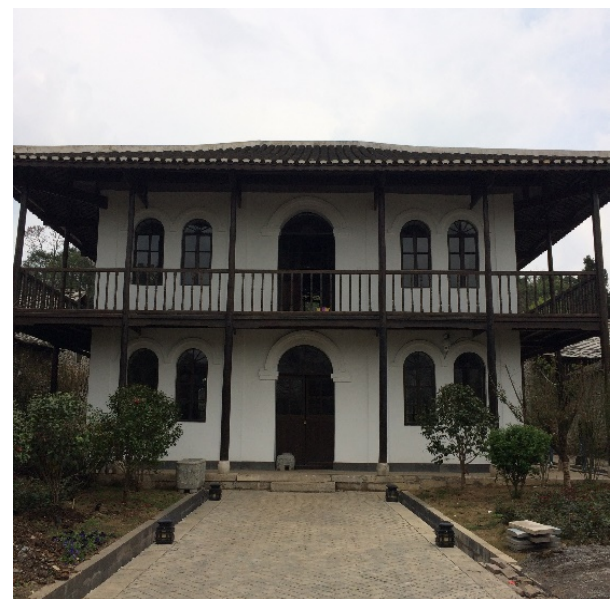

Figure 2. Ancient house of Lu family. Source: authors.

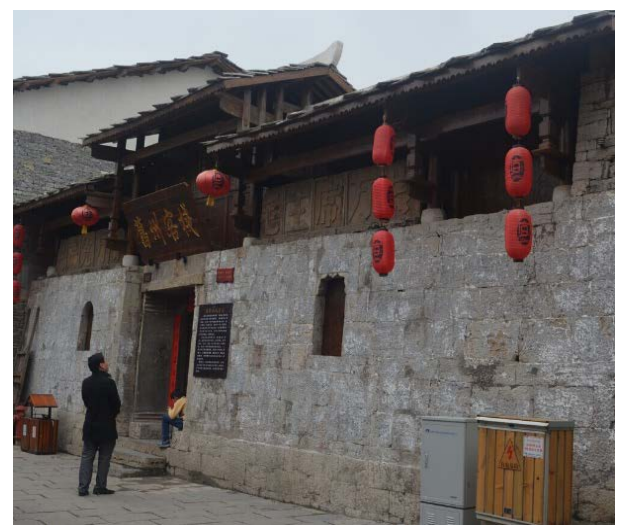

Figure 3. Jiuzhou Inn. Source: authors.

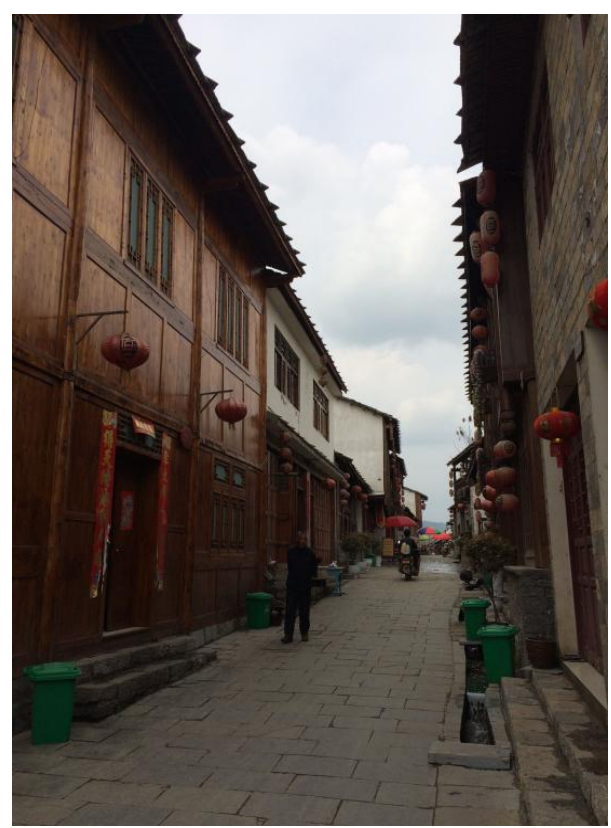

Figure 4. Jiuzhou streetscape. Source: authors. 
observed during their recent visits, a building boom has seemingly taken place particularly in the areas of hotels, sight-seeing spots and renewal or rehabilitation of the old centre. The capital input from the travel agencies is so large-scale that large tracts of farmlands, forest and other natural areas have obviously suffered great impact of destruction. With profit as their key objective, business investors have not given enough care to conserving the natural environment inclusive of waterbodies and the hilly terrains. Also, it is reported that conservation expertise has been inadequate as to how best to protect the historic and cultural heritage and objects. Moreover, rapid economic development of the urban economy in Jiuzhou has required more careful planning, management and trained personnel to run the tourism business (Zhang, 2015).

\section{Conclusion and Implications}

The study has found that there is close relationship between tourism development and the pace of urbanization, and local tourism development is capable to hold back local residents to an extent from flowing into large cities as migrants. As the tourism operations are very much urban-based, all infrastructure investment, capital-cum-asset building as well as tourist consumption pertaining to the hospitality business would have contributed towards strengthening an urban economy. Consequently, a township would be able to benefit from such a growth process, thus generating greater demand for goods and services. Such accumulative effects would lead correspondingly to the expansion of other related areas such as housing and higher levels of consumption pattern. By China's national urbanization strategy, the new pathway of rural urbanization through tourism development will be dependent on the rising sophistication of its functions and standards of services. Through positive interactive operations of such urbanization pathway and enhanced level of tourism, a more sustainable tourism-based economy could be built (Huang et al., 2015). Jiuzhou Township is endowed with considerable amounts of natural and ethnic-based cultural-historical assets, with which it will be capable of developing a rapidly growing country tourism attracting its visitors mainly from the cities. With substantial public support, the township has a potential to lead its farmers to move gradually towards a sustainable urban livelihood using their rural lands transformable into urban land use and activities.

There are however some developmental implications. It is reported that many state-run travel agencies lack market-led competition spirit, even though they may have captured a very large market share. Public authorities may be more interested in "image engineering" than the real substantive work, thus wasting lots of human and financial resources on formalities to publicize their performances (Li, 2011). Hence, it is felt that the role of the state should be more oriented towards providing guidance and policy evaluation or implementation rather than competing with the private sector for tourism businesses. Moreover, it is quite common that many rural tourism undertakers tend to ignore the im- 
portance of environmental protection and historic conservation. It is thus an increasingly important mission to educate and equip them with such mindset given that urbanization and economic growth have to be built upon an eternal survival of the natural ecosystems (Li \& Wang, 2015). The most ideal goal is after all to enhance both the economic and ecological values in the course of developing rural tourism, leading to a decent urban growth in harmony with nature.

\section{Acknowledgements}

The authors wish to thank those government officers and the interviewees who had provided warm reception and help during the field trips carried out in 2015 and 2016 in Jiuzhou.

\section{References}

Airey, D., \& Chong, K. (2010). National Policy-Makers for Tourism in China. Annals of Tourism Research, 37, 295-314.

Baidubaike. (2005). The Fifth Plenary Session of the 16th Central Committee of the Chinese Communist Party.

http://baike.baidu.com/view/2817413.htm?fromtitle=\%E4\%B8\%AD\%E5\%9B\%BD\%E5 \%85\%B1\%E4\%BA\%A7\%E5\%85\%9A\%E5\%8D\%81\%E5\%85\%AD\%E5\%B1\%8A\%E4\%B A\%94\%E4\%B8\%AD\%E5\%85\%A8\%E4\%BC\%9A\&fromid=8431238\&type=syn

Baidubaike. (2015). Jiuzhou Township of Xixiu County, Anshun Municipality, Guizhou Province.

http://baike.baidu.com/link?url=IXzY4zCBY3d5xnbxozLgzucK4OWK8q0PHFEONYj

KnjwxLNudz-

cUcimcCsAz3LPynQC3jA5X4JixNThxsVxM-GFdJEJSW_GcNNx7xo8ia1W3

Baidubaike. (2016). Anshun Municipality.

http://baike.baidu.com/link?url=ZkdQDttY4f_xHp_X9p_8LL0x5VXgCIkzJzkX4909z_j $\underline{\text { Rpe- }}$

FLyeL-5x9MX2gLhDfpx3On_49iVA4NCR7hMiAD_1P5kL1znzW-bfPi3DHmWPW

China National Tourism Administration (CNTA). (2014). National 4A Class Tourism Site List on Website.

http://www.cnta.gov.cn/zwgk/tzggnew/gztz/201506/t20150625_429514.shtml

Dong, C. W. (2014). Research on the Tourism Urbanization Patterns and Dynamic Mechanisms. Master's Thesis, Submitted to the Northeast Normal University. (In Chinese)

Fan, T., Yang, S. Y., \& Li, J. (2007). The Study of the Coordinative Development between Rural Eco-Tourism and Urbanization in Tuanjie Township. Resource Development \& Market, 23, 1045-1048.

Fan, Z. T. (2015). An Analysis of the Relationship between Rural Urbanization and Urbanization. Guangxi Agricultural Sciences, 9, 122-123.

Fenghuangwang (2015) China's Tourism Investment Report, 2014. http://travel.ifeng.com/news/china/detail_2015_05/15/41047646_0.shtml

Han, W. M. (2007). The Study of Rural Urbanization with the Chinese Characteristics. Master's Thesis Submitted to the Harbin University of Technology. (In Chinese)

Huang, Z. L., Lu, L., Su, J,, Zhang, J. H., Sun, J. X., Wan, X. C., \& Jin, C. (2015). Rural Tourism against the Background of New Style Urbanization: A Theoretical Reflection 
and Breakthrough. Geographical Research, 34, 1409-1421.

Jiang, H. Z. (2010). An Analysis of the Interactive Development of Regional Level Tourism and Urbanization in the Minority Areas of Guizhou: A Case Study of Luizhou. Journal of Anhui Agricultural Sciences, 38, 18530-18532.

Jinqian Zaixian (2012). Rural Tourism: Important Growth Pole of "Golden Goose" Tourism in Guizhou. http://travel.gog.cn/system/2012/06/07/011478481.shtml

Jinri Toutiao (2016). Let's Look at Jiuzhou Township of Today-We Have Found the Potential in Historical Guizhou. http://toutiao.com/a6255059566326153474/

Li, L. H. (2011). The Study of Urbanization in Less Developed Regions. Manager Journal, $24,37$.

Li, Y. L., \& Wang, C. (2015). An Exploratory Study of the Transition into Rural Ecological Tourism under the New Style of Urbanization in China. Agricultural Economy, 6, 29-34.

Lu, L., \& Ge, J. B. (2006). The Progress and Implications of Tourism-Led Urbanization Study. Geographical Research, 25, 741-749.

Lu, Y., Feng, C. X., \& Yang, Z. J. (2013). Beautiful China: Study of the Rural Tourism Development Model. Yangtze University Journal, 36, 70-72.

Lu, Y. Q. (2015). Central Government Document No. 1 Focus: 1.2 Billion Rural Tourists in 2014 with a Revenue of 320 Billion Yuan. http://www.dotour.cn/article/11930.html

Pons, A., Salamancha, O. R., \& Murray, I. (2014). Tourism Capitalism and Island Urbanization: Tourist Accommodation Diffusion in the Balearics, 1936-2010. Island Studies Journal, 9, 239-258.

Wang, X. F. (2014). Research on the Interrelationship between Urbanization and Tourism. In Proceedings of Eastern Academic Forum (pp. 761-766). http://www.seiofbluemountain.com/upload/product/201410/2014mid8h15.pdf

Wong, T.-C. (2015). Exploring Sustainable Tourism Development in Mountainous Guizhou Province, China. Journal of Hospitality and Tourism Management, 6, 60-70. https://doi.org/10.5897/JHMT2015.0153

Xiao, W. C. (2005). A Research on Rural Urbanization of China. PhD Thesis Submitted to the Central Party School of the Communist Party of China. (In Chinese)

Zhang, G. J. (2015). New Thought on Tourism Planning of Historical and Cultural Town: A Case Study of Jiuzhou Tourism Planning. Architectural Engineering Technology and Design, 32, 416.

Zhang, H. Q., Luo, J. M., Xiao, Q., \& Guillet, B. D. (2013). The Impact of Urbanization on Hotel Development: Evidence from Guangdong Province in China. International Journal of Hospitality Management, 34, 92-98.

Zhang, J., \& Li, S. T. (2015). The Study of Rural Tourism Pathway against the Background of New Style Urbanization. Development \& Research, 6, 49-53.

Zhen, T. X., \& Luo, H. Y. (2007). The Mutual Influence of Rural Tourism and Urbanization. Journal of Hunan University of Humanities, Science and Technology, 2, 68-70. 